\title{
The effect of preoperative albendazole treatment on the cuticular membranes of pulmonary hydatid cysts: should it be administered preoperatively?
}

\author{
Ozan Usluer, Seyda Ors Kaya, Ozgur Samancilar, Kenan Can Ceylan, Soner Gursoy \\ Izmir Dr Suat Seren Chest Disease and Thoracic Surgery Training and Research Hospital, \\ Department of Thoracic Surgery, Izmir, Turkey
}

Kardiochirurgia i Torakochirurgia Polska 2014; 11 (1): 26-29

\begin{abstract}
The aim of this study was to investigate the effects of preoperative albendazole treatment on the tensile strength of the $\mathrm{cu}$ ticular membranes of pulmonary hydatid cysts.

Material and methods: A study including 44 patients operated on for pulmonary hydatid cysts was carried out between January 2009 and November 2010. The patients were divided into two groups according to their preoperative albendazole administration. Seventeen patients (with 20 cysts) in group A were operated on after three cycles of peroral $10 \mathrm{mg} / \mathrm{kg} / \mathrm{day}$ albendazole treatment, whereas 27 patients (with 29 cysts) in group $B$ underwent the operation without any preoperative administration of albendazole. Fresh tissue tensile stress tests were carried out on the cuticular membranes excised from both groups.

Results: The results of this study demonstrated that the tensile strength values of the cuticular membrane of the cysts excised from group A were lower than those obtained from group $B$, with a statistically significant difference.

Conclusions: Albendazole treatment decreases the tensile strength of the cuticular membranes of pulmonary hydatid cysts, which may lead to their perforation. The patients should be operated on as soon as possible and without any preoperative medical treatment in order to prevent complications before the definitive surgical operation.
\end{abstract}

Key words: hydatid disease, lung, albendazole, in vitro studies, surgery.

\section{Introduction}

Hydatid disease is the most common cause of pulmonary cysts in endemic countries. A lack of satisfactory preventive medicine increases the incidence of the disease. Hydatid cysts carry a risk of rupture, which may lead to several complications. Surgery is normally the most effective method for treating pulmonary hydatid cysts. On the other

\section{Streszczenie}

Celem pracy było zbadanie wpływu przedoperacyjnego leczenia albendazolem na błonę oskórkową torbieli bąblowca w płucach.

Materiat i metody: Badaniem objęto 44 osoby operowane z powodu obecności torbieli bąblowca w płucach pomiędzy styczniem 2009 a listopadem 2010 r. Pacjenci zostali podzieleni na dwie grupy zgodnie z przedoperacyjnym podawaniem albendazolu. Siedemnastu pacjentów (z 20 torbielami) w grupie A otrzymywało przed operacją 3 doustne cykle albendazolu w dawce $10 \mathrm{mg} / \mathrm{kg}$ m.c./dobę, podczas gdy 27 pacjentów (z 29 torbielami) w grupie B nie otrzymywało przed operacją albendazolu. Testy wytrzymałości na rozciąganie przeprowadzano na świeżych tkankach błon oskórkowych usuwanych z płuc pacjentów obu grup.

Wyniki: Wykazano, że wartości wytrzymałości na rozciąganie błon oskórkowych torbieli wycinanych w grupie A były niższe niż uzyskane $w$ grupie $B$, a różnica pomiędzy nimi była istotna statystycznie.

Wnioski: Leczenie albendazolem zmniejsza wytrzymałość na rozciąganie błon oskórkowych płucnych torbieli bąblowca, co może prowadzić do ich perforacji. Chorzy powinni być operowani w najszybszym możliwym terminie, bez dodatkowej terapii przedoperacyjnej, aby uniknąć powikłań przed definitywnym leczeniem chirurgicznym.

Słowa kluczowe: bąblowica, płuco, albendazol, badania in vitro, chirurgia.

hand, albendazole treatment is the most commonly used regime for pre- and post-operative antihelminthic treatment and for inoperable hydatid cysts. There is a tendency among physicians to treat parasitic diseases with medical therapy, especially in the case of pediatric patients, but it is also very well known that this strategy may lead to preoperative complications and delay the definitive surgical thera-

Address for correspondence: Ozan Usluer, Izmir Dr Suat Seren Chest Disease and Thoracic Surgery Training and Research Hospital, Department of Thoracic Surgery, Gogus Hastanesi Tepecik Yenisehir Konak, 35040 Izmir, Turkey, phone: +0905057768059, e-mail: ozanusluer@yahoo.com 
py. It must be taken into consideration that postoperative morbidity may also be related to preoperative albendazole treatment.

\section{Aim of the study}

The aim of this study is to show the mechanical effect of preoperative albendazole treatment on the cuticular membrane and investigate the role of albendazole treatment on the tensile strength of pulmonary hydatid cyst structures.

\section{Material and methods}

The study included 44 patients operated on between January 2009 and November 2010 with the diagnosis of hydatid cyst of the lung. All the patients consented to all scientific research before the treatment and the operations.

All the patients were evaluated by chest X-ray and computed tomography (CT) scans of the chest. Moreover, ultrasonography of the abdomen was carried out before the operation in order to determine whether hydatid cysts were present in the liver.

The patients were divided into two groups according to their preoperative albendazole administration. In group A, the patients received 3 cycles of preoperative albendazole treatment of $10 \mathrm{mg} / \mathrm{kg}$ per day for their concomitant hydatid disease. In group B, the patients were operated on without the preoperative administration of albendazole.

Tensile stress tests were carried out ex vivo on freshly excised cuticular membranes from both groups. The breaking force was recorded in kilograms and was defined as the maximum force that the strips could withstand before failure.

We used a tensiometer which was designed to test the tensile strength of medical sutures (manufactured by Mark-10, model MG50). The machine is designed as a mechanical device for testing sutures with regard to predetermined pulling. A cuticular membrane segment is mounted in the tensile testing machine, and a 2-0 monofilament suture with an atraumatic needle is passed through each wall at a distance of $2 \mathrm{~mm}$ from the end (Fig. 1). The suture is then pulled at a constant rate until the cuticular membrane ruptures. The resulting peak force is measured in kilograms and then converted to newtons.

\section{Statistical analysis}

Statistical Package for the Social Sciences (SPSS) version 19 was used for analyzing the data. The compliance of quantitative variables with the assumption of normal distribution was examined by the Kolmogorov-Smirnov test. The analyses of the variables which were assumed to have normal and abnormal distributions were conducted by utilizing parametric and nonparametric statistical methods, respectively.

The parametric independent samples $t$-test and the Mann-Whitney $U$ test were implemented for the pairwise comparisons of the independent groups. The associations among the categorical variables and numerically coded qualitative variables were examined by using Kendall's tau-b test and Fisher's exact test, respectively. The descriptive statistics of the quantitative variables were reported as means, standard deviations, medians, minimums, and maximums, while the qualitative variables were summarized as counts ( $n$ ) and percentages (\%). The obtained statistics were reported with their $95 \%$ confidence intervals, and the analysis results with the value of $p<0.05$ were considered as statistically significant.

\section{Results}

There were 17 patients having 20 cysts (41\%) in the albendazole group (group A), of whom 11 were female (35\%) and 6 were male (17\%). The mean age of group A patients was 38.6 years (range: $21-61$ ). In the non-albendazole group (group B), there were 27 patients: 14 female (52\%) and 13 male (48\%) with 29 cysts (59\%) (Fig. 2, 3). Their mean age was 37.9 years (range: 17-67).

The most common symptom in group A was chest pain, while in group B it was coughing. Other symptoms included hemoptysis, fatigue, dyspnea, vomiting, and hydatoptysis. The percentages of symptomatic patients in groups $A$ and B were $80 \%$ and $82.7 \%$, respectively $(p=0.716)$.

In group $A$, all the patients underwent drainage-capitonnage or cystectomy. Pleurectomy and decortication without lobectomy were required in 2 patients (17\%). In group $B$, on the other hand, 2 patients (7\%) required lobectomy, and the remaining 25 patients underwent drainage-capitonnage or cystectomy. Pleurectomy with decortication was performed in 7 of these patients (26\%). The clinical characteristics of both groups are presented in Table I.

The values of tensile strength of the cuticular membranes excised in group A were lower than those of the patients in group $B$, and the difference was statistically significant $(p<0.001)$ (Table II). The tensile strength values of the perforated cysts were also lower than those of the non-perforated (intact) cysts, and the difference proved to be statistically significant $(p=0.001)$ (Table III). The ratio of cyst rupture was higher in group $A$ (5/20 in group $A$ vs. $8 / 29$ in group $B)$, but not significantly different $(p=1)$. The tensile strength of the cuticular membranes did not decrease as the diameter of hydatid cysts increased $(p=0.069)$.

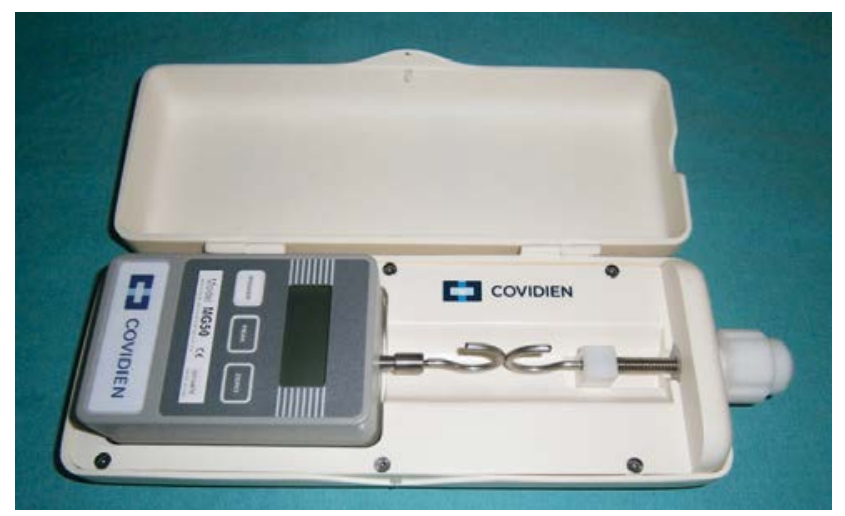

Fig. 1. Photograph of the tensiometer that was used in the study 
The effect of preoperative albendazole treatment on the cuticular membranes...

Tab. I. General characteristics of the patients

\begin{tabular}{|c|c|c|c|c|}
\hline Variable & All patients & Albendazole group & Non-albendazole group & $p$ value \\
\hline Age $($ mean \pm SD) & $38.3 \pm 13.4$ & $38.6 \pm 14.0$ & $37.9 \pm 12.8$ & 0.871 \\
\hline Sex (male/female) & $19 / 25$ & $6 / 11$ & $13 / 14$ & - \\
\hline Cysts & 49 & 20 & 29 & - \\
\hline Perforated/non-perforated & $14 / 35$ & $6 / 14$ & $8 / 21$ & 1.0 \\
\hline Cyst diameter $[\mathrm{cm}]($ mean $\pm \mathrm{SD})$ & $6.1 \pm 3.5$ & $7.4 \pm 3.6$ & $4.1 \pm 2.3$ & 0.069 \\
\hline Symptoms & 11 & 5 & 4 & 0.716 \\
\hline \multicolumn{5}{|l|}{ Concomitant disease } \\
\hline Liver & 11 & 11 & - & - \\
\hline Spleen & 2 & 2 & - & - \\
\hline Heart & 1 & 1 & - & - \\
\hline Recurrent disease & 2 & 2 & - & - \\
\hline
\end{tabular}

Tab. II. Tensile strength measured for the two study groups

\begin{tabular}{|c|c|c|c|c|c|c|}
\hline \multirow[t]{2}{*}{ Variable } & \multicolumn{6}{|c|}{ Tensile strength [newtons] } \\
\hline & Mean & SD & Median & Max. & Min. & $p$ value \\
\hline Albendazole group & 1.76 & 0.13 & 1.80 & 2.00 & 1.50 & \\
\hline Non-albendazole group & 2.04 & 0.19 & 2.00 & 2.40 & 1.70 & \\
\hline
\end{tabular}

SD - standard deviation, max. - maximum, min. - minimum

Tab. III. Tensile strength measured for perforated and non-perforated cysts

\begin{tabular}{lccccccc} 
Variable & \multicolumn{7}{c}{ Tensile strength [newtons] } \\
\cline { 2 - 7 } & Mean & SD & Median & Max. & Min. & $p$ value \\
Non-perforated cysts & 1.99 & 0.21 & 2.00 & 2.40 & 1.60 & $<0.001$ \\
\hline Perforated cysts & 1.76 & 0.17 & 1.80 & 2.00 & 1.50 & \\
\hline
\end{tabular}

SD - standard deviation, max. - maximum, min. - minimum

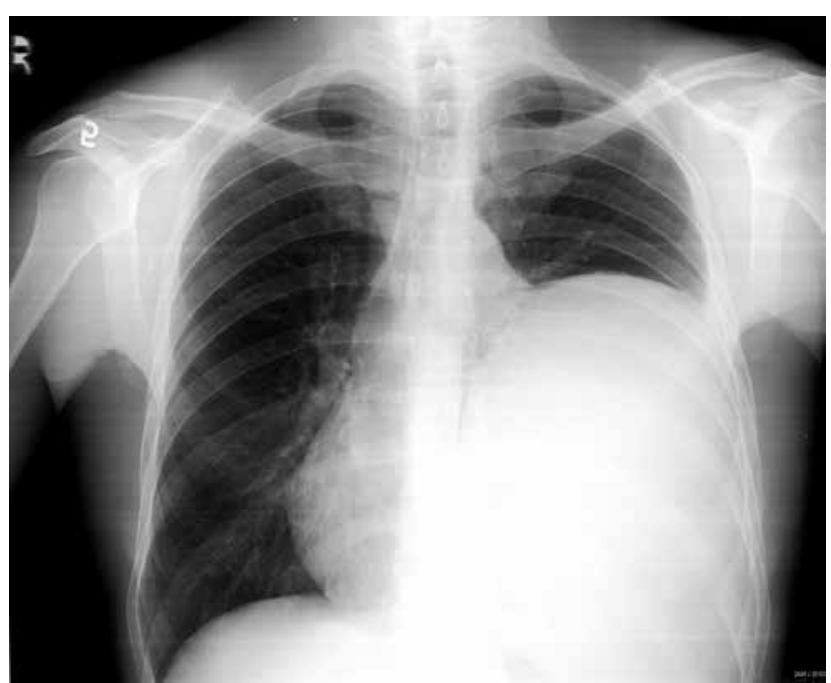

Fig. 2. Chest $\mathrm{X}$-ray of a giant cyst in the non-albendazole group

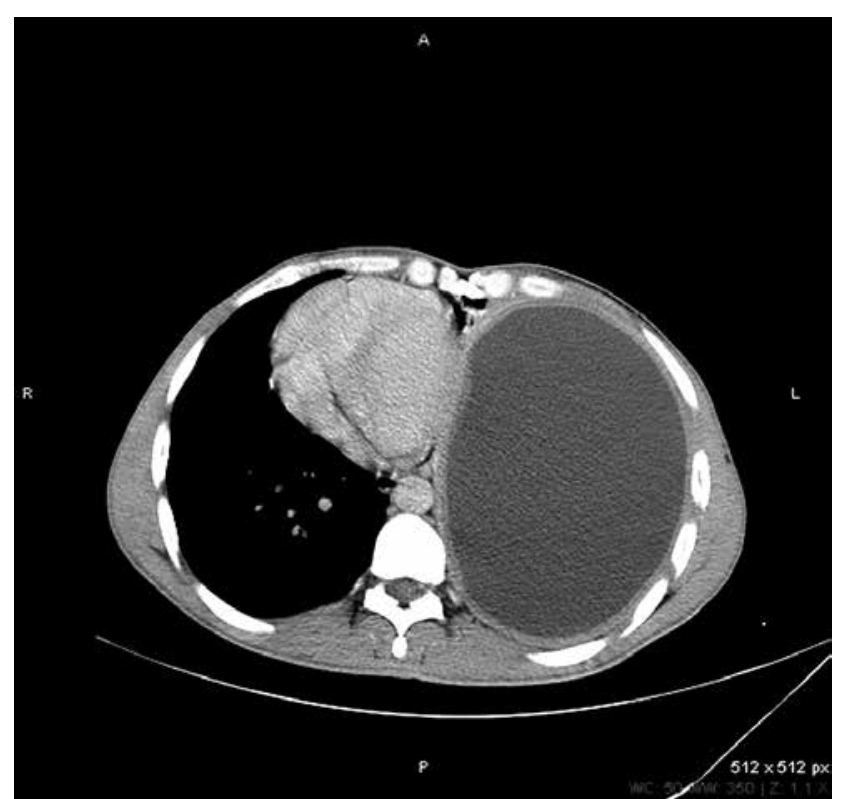

Fig. 3. Computed tomography scan of the patient presented in Figure 2 


\section{Discussion}

Surgery is presently the definitive treatment method in the majority of pulmonary hydatid disease cases, but the benign parasitic nature of the disease may lead health professionals to attempt to cure the disease with medical therapy. Medical treatment with albendazole for Echinococcus infection is described in different studies, and the cure rates are estimated at between $34 \%$ and $57 \%$ [1, 2]. The compounds of benzimidazole lower the glycogen levels by interfering with glucose absorption through the hydatid cyst membrane. The endoplasmic reticulum and mitochondria of germinal cells undergo degenerative changes, while cellular autolysis arises from the increase in lysosome number and activity [3]. Certain researchers have found the presence of albendazole sulfoxide, which is the principal metabolite of albendazole in the cyst fluid. Patients who were treated for more than 24 hours had high concentration levels of this metabolite [4]. The cyst can continue to be viable despite a high concentration of albendazole in the serum and cyst fluid; moreover, protoscoleces maintain their viability in dead cysts [5]. The membranes remaining in the lung become a source of infections, even after the death of the parasite [6]. The germinal layer may remain intact or only partially damaged between the third and the fourteenth day of ongoing treatment [5].

Several studies have reported the rupture of the hydatid cyst during or after albendazole treatment [4-7]. The rupture of the cyst may lead to several complications. The rupture of the hydatid cyst into an adjacent bronchus may be indicated by coughing and expectorating significant amounts of salty sputum and hydatid fluid, as well as fragments of the laminated membrane. Moreover, a complete tracheal obstruction by the fragments of the hydatid membrane can cause sudden and severe dyspnea, which may be followed by suffocation and death. The patient may undergo a severe hypersensitivity reaction, displaying symptoms of generalized rash, high fever, bronchospasm, and pulmonary congestion [8]. Severe hemoptysis requiring urgent surgery and life-threatening hypersensitivity reactions resulting from cyst rupture during albendazole treatment are also reported [2-9]. Wen and Yang write that antihelminthics weaken the cyst wall, thus increasing the possibility of rupture. Among 21 patients with hydatid disease, who underwent albendazole treatment, the said researchers found a $77.3 \%$ incidence of cyst rupture [1]. Keramidas et al. reported a $30 \%$ complication rate after albendazole treatment for large pulmonary cysts: most of the complications presented approximately two months after the beginning of treatment, and all the affected patients required surgical therapy [10]. They also found that suturing the ruptured bronchi was especially difficult due to coexisting infection; this situation resulted in air leakages in three patients during the early postoperative period. We have also faced the same complication in our patients who received albendazole treatment before the operation.

In this study, the tensile strength of the membrane decreased in the albendazole group, leading to weakening of the mechanical durability of the membrane. This, in turn, might lead to cyst rupture and result in fatal complications. The tensile strength values of the membrane were also lower in the perforated cysts, which supports the hypothesis of the study.

\section{Conclusions}

Preoperative albendazole treatment weakens the walls of pulmonary cysts and might cause their rupture, resulting in complications; it should not, therefore, be applied to patients who are candidates for surgical treatment. Albendazole may be administered to patients with ruptured or multiple cysts preoperatively, or it can be applied postoperatively to patients having a risk of intraoperative spillage or patients with giant cysts to prevent recurrence.

\section{References}

1. Wen H, Yang WG. Public health importance of cystic echinococcosis in China. Acta Trop 1997; 67: 133-145.

2. Dogan R, Yuksel M, Cetin G, Suzer K, Alp M, Kaya S, Ünlü M, Moldibi B. Surgical treatment of hydatid cysts of the lung: report on 1055 patients. Thorax 1989; 44: 192-199.

3. Khuroo MS, Dar MY, Yattoo GN, Zargar SA, Javaid G, Khan BA, Boda MI. Percutaneous drainage versus albendazole therapy in hepatic hydatidosis: a prospective, randomized study. Gastroenterology 1993; 104: 1452-1459.

4. Morris DL, Chinnery JB, Georgiou G, Stamatakis G, Golematis B. Penetration of albendazole sulphoxide into hydatid cysts. Gut 1987; 288: 75-80.

5. Saimot AG, Meulemans A, Cremieux AC, Giovanangeli MD, Hay JM, Delaitre B, Coulaud JP. Albendazole as a potential treatment for human hydatidosis. Lancet 1983; 17: 652-656.

6. Peleg H, Best LA, Gaitini D. Simultaneous operation for hydatid cysts of right lung and liver. J Thorac Cardiovasc Surg 1985; 90: 783-787.

7. Cobanoglu U, Sayir F, Sehitoglu A, Bilici S, Melek M. Therapeutic strategies for complications secondary to hydatid cyst rupture. Int J Clin Exp Med 2011; 4: 220-226.

8. Aletras H, Symbas PN. Hydatid disease of the lung. In: Shields TW, LoCicero III J, Ponn RB, Ponn RB (eds.). General thoracic surgery. Lippincott Williams \& Wilkins, Philadelphia 2000; pp. 1113-1122.

9. Kurkcuoglu IC, Eroglu A, Karaoglanoglu N, Polat P. Complication of albendazole treatment in hydatid disease of lung. Eur J Cardiothorac Surg 2002; 22: 649-650.

10. Keramidas D, Mavridis G, Soutis M, Passalidis A. Medical treatment of pulmonary hydatidosis: complications and surgical management. Pediatr Surg Int 2004; 19: 774-776. 